\section{Sweetpotato Cultivar Trials on Hawai'i Island}

\author{
Susan C. Miyasaka ${ }^{1}$, Marisa Wall ${ }^{2}$, Don LaBonte ${ }^{3}$, \\ and Alton Arakaki ${ }^{4}$
}

AdDitional INDEX wORDs. anthocyanins, $\beta$-carotene, Cylas formicarius elegantulus, human nutrition, Ipomoea batatas var. batatas, pest resistance, sugars, sweetpotato weevil

\begin{abstract}
Summary. Twelve sweetpotato (Ipomoea batatas var. batatas) accessions/cultivars/ landraces (entries) were evaluated for yield, resistance to pests, and quality in five field trials planted at Pepe'ekeo, Hawai'i Island, and replicated over time with blocks planted on May and Oct. 2014, Feb. and July 2015, and Jan. 2016. Plots were harvested at 4.5 to 6 months after planting. In the first two field trials, local entries planted were 'Okinawan', 'Mokuau', and 'Kona B', as well as PI 531094, 'Beauregard', PI 573309, PI 573330, 'Darby', 'Pelican Processor', and 'Picadito'. Yields of 'Mokuau' and 'Kona B' were low and were replaced in the latter three field trials with 'Murasaki-29' and 'LA 08-21p' from Louisiana State University (LSU) AgCenter, Baton Rouge. At harvest, storage roots were graded according to State of Hawai' $i$ standards and marketable yields included grades AA, A, and B. Then, injuries of storage roots due to infestations of sweetpotato weevil (Cylas formicarius elegantulus) in each category were estimated. Finally, sugar concentrations, anthocyanins, and $\beta$-carotene contents were measured in storage roots. Marketable fresh weight yields of entries differed significantly, with 'LA 08-21p' having the greatest marketable yield. However, 'LA 08-21 p' also had the greatest incidence of damage due to sweetpotato weevil, perhaps because of its growth habit as a tight cluster of storage roots located close to the soil surface. Entries also had significantly different sugar concentrations (fructose, glucose, sucrose, maltose, and total sugars). Concentrations of sucrose ranged from 25 to $68 \mathrm{mg} \cdot \mathrm{g}^{-1}$ fresh weight and were greater than those of monosaccharides analyzed. 'Beauregard' had the highest sucrose concentration and total sugars. Purple-fleshed cultivars Okinawan and LA 08-21p contained total monomeric anthocyanins that ranged from 34 to 37 $\mathrm{mg} / 100 \mathrm{~g}$ dry weight. Orange-fleshed cultivars Beauregard and Darby contained $\beta$-carotene that ranged from 5485 to $8302 \mu \mathrm{g} / 100 \mathrm{~g}$ fresh weight. These results provide yields of storage roots, susceptibility to sweetpotato weevils, and amounts of antioxidants in purple- and orange-fleshed sweetpotato cultivars to growers interested in producing new sweetpotato cultivars.
\end{abstract}

S weetpotato is a nutritious source of food. Orange-fleshed cultivars are rich in $\beta$-carotene and purple-fleshed cultivars are rich in anthocyanins, both of which are important dietary antioxidants (Teow et al., 2007; Wang et al., 2016). In the state of Hawai' $i$, most sweetpotato production is on the east coast of Hawaici Island, where the purplefleshed landrace Okinawan is grown and exported to the U.S. mainland.

Sweetpotato production in Hawaici increased 7-fold between 2002 and 2011 from 2.3 million pounds to 16.7 million pounds and a farm gate value from $\$ 0.99$ million to $\$ 7.3$ million [Hawaici Department of Agriculture (HDOA), 2013, 2004]. This increased production was due largely to an increased export market after approval of quarantine treatments to control insect pests (Follett, 2006).

However, by 2016, area harvested for sweetpotato in Hawai' $i$ decreased from 1100 to 485 acres and farm gate value decreased to $\$ 1.18$ million (HDOA, 2018). Problems that threaten the sustainability of the industry are as follows: 1) extreme offgrade shapes and sizes and inconsistencies in flesh color and 2) quarantine insect pests that negatively impact production and quality. A sweetpotato breeding program is needed in Hawai'i to improve the consistency of shapes, sizes, and purple flesh color, as well as to improve resistance to insect pests.

The two major quarantine pests that adversely affect sweepotato production in Hawai'i are sweetpotato weevil and sweetpotato vine borer [Omphisa anastomosalis (Follett, 2006)]. Sweetpotato weevil larvae feed and develop within the storage root of sweetpotato, making it difficult to control the larvae with insecticides and resulting in inedible storage roots (Thompson et al., 1999). Crop losses in Hawai'i due to the sweetpotato weevil have been reported to range from $15 \%$ to $30 \%$ but could be as high as $60 \%$ to $97 \%$ if pest populations were not controlled (Valenzuela et al., 1994). Sweetpotato weevil is found worldwide and could cause crop losses of up to $80 \%$ (Nottingham and Kays, 2002).

Significant differences have been found among sweetpotato entries in resistance to injury of storage roots by insects, in particular by sweetpotato weevils of the genus Cylas (Jackson and Bohac, 2006; Jackson and Harrison, 2013; Jackson et al., 2012; Stathers et al., 2003a; Thompson et al., 1999). Resistance to sweetpotato weevils is likely a combination of antibiosis, tolerance, escape, and nonpreference (Stathers et al., 2003b). A poor correlation was found between results of laboratory studies (e.g., antibiosis studies and root choice) and those of field studies (Stathers

\begin{tabular}{lllc}
\hline $\begin{array}{l}\text { Units } \\
\begin{array}{l}\text { To convert U.S. to SI, } \\
\text { multiply by }\end{array}\end{array}$ & U.S. unit & SI unit & $\begin{array}{l}\text { To convert SI to U.S., } \\
\text { multiply by }\end{array}$ \\
\hline 0.4047 & $\mathrm{acre}(\mathrm{s})$ & $\mathrm{ha}$ & 2.4711 \\
29,574 & $\mathrm{fl} \mathrm{oz}$ & $\mu \mathrm{L}$ & $3.3814 \times 10^{-5}$ \\
29.5735 & $\mathrm{fl} \mathrm{oz}$ & $\mathrm{mL}$ & 0.0338 \\
0.3048 & $\mathrm{ft}$ & $\mathrm{m}$ & 3.2808 \\
2.54 & inch $(\mathrm{es})$ & $\mathrm{cm}$ & 0.3937 \\
25.4 & inch $(\mathrm{es})$ & $\mathrm{mm}$ & 0.0394 \\
0.4536 & $\mathrm{lb}$ & $\mathrm{kg}$ & 2.2046 \\
1.1209 & $\mathrm{lb} / \mathrm{acre}$ & $\mathrm{kg} \cdot \mathrm{ha}^{-1}$ & 0.8922 \\
1 & $\mathrm{micron}(\mathrm{s})$ & $\mu \mathrm{m}$ & 1 \\
1.6093 & $\mathrm{mile}(\mathrm{s})$ & $\mathrm{km}$ & 0.6214 \\
28.3495 & $\mathrm{oz}$ & $\mathrm{g}$ & 0.0353 \\
70.0532 & $\mathrm{oz} / \mathrm{acre}$ & $\mathrm{g} \cdot \mathrm{ha}^{-1}$ & 0.0143 \\
0.1 & $\mathrm{ppb}$ & $\mu \mathrm{g} / 100 \mathrm{~g}$ & 10 \\
0.1 & $\mathrm{ppm}$ & $\mathrm{mg} / 100 \mathrm{~g}$ & 10 \\
0.001 & $\mathrm{ppm}$ & $\mathrm{mg} \cdot \mathrm{g}^{-1}$ & 1,000 \\
$\left({ }^{\circ} \mathrm{F}-32\right) \div 1.8$ & ${ }^{\circ} \mathrm{F}$ & ${ }^{\circ} \mathrm{C}$ & $\left({ }^{\circ} \mathrm{C} \times 1.8\right)+32$ \\
& & &
\end{tabular}


et al., 2003b), demonstrating the importance of conducting cultivar trials in the field.

Most consumers in the United States prefer sweetpotatoes with sweet, moist, and orange flesh. 'Beauregard' is a popular, commercial, orange-fleshed cultivar grown in the United States (Jackson and Bohac, 2006; Jackson and Harrison, 2013). Unfortunately, it is susceptible to injury by several insects, including sweetpotato weevil (Jackson and Harrison, 2013; Jackson et al., 2012; Thompson et al., 1999). In Hawai'i,

Received for publication 19 Apr. 2019. Accepted for publication 21 Aug. 2019

Published online 8 October 2019

${ }^{1}$ Department of Tropical Plant and Soil Sciences, University of Hawai'i at Manoa, 875 Komohana Street, Hilo, HI 96720

${ }^{2}$ U.S. Department of Agriculture, Agricultural Research Service, Daniel K. Inouye U.S. Pacific Basin Agricultural Research Center, 64 Nowelo Street, Hilo, HI 96720

${ }^{3}$ Louisiana State University AgCenter, 104B M.B. Sturgis Hall, Baton Rouge, LA 70803

${ }^{4}$ Department of Tropical Plant and Soil Sciences, University of Hawai' $i$ at Manoa, Molokai Extension Office and Applied Research Farm, P.O. Box 6729, Hoolehua, HI 96729

This project was funded by the County of Hawaii Department of Research and Development and by the U.S. Department of Agriculture National Institute of Food and Agriculture Hatch project \#08029-H, and managed by the University of Hawai' $i$ Manoa College of Tropical Agriculture and Human Resources. We would like to acknowledge the dedication and hard work of agricultural technician Layne Matsushita at the Waiakea Research Station, who capably organized and carried out the installation, maintenance, and harvesting of these sweetpotato cultivar trials. We would like to thank farm manager Angel Magno and other agricultural technicians at the Waiakea Research Station who assisted in these field trials: Christopher Bernabe, Mary Kaheiki, Ryan Kaneko, Jon Katada, Eric Magno, and Dayle Tsuha. Also, we would like to thank landowners Steve and Lucy Meeks, and Robert $S$. Gove for allowing us to conduct these studies on their farms. We thank the U.S. Department of Agriculture-Agriculture Research Service Biological Science technicians Julie Duhaylongsod, Sandra Silva, and Suzanne Sanxter for their compositional analyses. Mention of a trademark, proprietary product, or vendor does not constitute a guarantee or warranty of the product by the University of Hawai'i Manoa, Louisiana State University, or the U.S. Department of Agriculture, and does not imply its approval to the exclusion of other products or vendors that might also be suitable.

S.C.M. is a Professor of Agronomy.

M.W. is the Center Director of Daniel K. Inouye Pacific Basin Agricultural Research Center.

D.L. is a Professor, School of Plant, Environmental, and Soil Sciences.

A.A. is an Assistant Extension Agent.

S.C.M. is the corresponding author. E-mail: miyasaka@ hawaii.edu.

This is an open access article distributed under the CC BY-NC-ND license (https://creativecommons.org/ licenses/by-nc-nd/4.0/).

https://doi.org/10.21273/HORTTECH04387-19 consumers prefer sweetpotatoes with sweet, drier, purple flesh because they are familiar with the Okinawan landrace.

In a series of field trials at Pepe'ekeo, HI, we evaluated sweetpotato entries grown on Hawai'i Island for yield of storage roots, resistance to insect pests, and quality. The overall goal was to identify alternative cultivars for commercial production, as well as superior sources of germplasm for breeding high-yielding, nutritious sweetpotatoes with tolerance to insect pests under tropical conditions.

\section{Materials and methods}

Preliminary field trials of 57 sweetpotato entries were conducted over three cropping cycles. Twelve sweetpotato entries (Table l) were selected for evaluation on a larger scale in Pepe cekeo, HI (lat. $19.835^{\circ} \mathrm{N}$, long. $155.102^{\circ} \mathrm{W}$ ).

Sweetpotato accessions were obtained originally as disease-tested, tissue-cultured plantlets from the U.S. Department of Agriculture (USDA) Germplasm Repository in Griffin, GA. Cultivars Murasaki-29 and LA 08-2lp were obtained as disease-tested, tissue-cultured plantlets from Louisiana State University AgCenter (Baton Rouge). These entries were multiplied by a commercial tissue culture laboratory, planted in pots; cuttings were taken and planted in the field, and then multiplied for field trials. Cuttings of local entries were obtained from either the Molokai Applied Research Farm (Hoolehua, HI) or commercial growers.

Trial plots were $5 \times 30 \mathrm{ft}$ and planted by hand, with 30 cuttings spaced $1 \mathrm{ft}$ apart. Trials were replicated over time because of limited field space. 'Okinawan' was selected as the control because it is the main commercial sweetpotato landrace grown on Hawai'i Island. After two field trials, local entries 'Mokuau' and 'Kona B' had dramatically lower yields and so were replaced in latter trials by 'Murasaki-29' and 'LA 082lp'. 'Murasaki-29' is a sweetpotato cultivar with white flesh, dark purple skin, broad-spectrum disease resistance, and resistance to the southern root-knot nematode [Meloidogyne incognita (LaBonte et al., 2008)]. 'LA 08-2lp', an advanced breeding line from LSU AgCenter, has purple flesh, red skin, resistance to the southern root-knot nematode, and resistances to java black rot (Diplodia gossypina), bacterial root rot (Erwinia chrysanthemi), fusarium root rot (Fusarium solani), rhizopus soft rot (Rhizopus sp.), and fusarium wilt (Fusarium oxysporum f.sp. batatas).

Soil series is the Hilo series (medial over hydrous, ferrihydritic, and isohyperthermic Acrudoxic Hydrudands). Field trials were located within a 10-acre area on two neighboring farms in Pepe'ekeo. Before planting, one to two soil samples per experimental field were analyzed by the University of Hawai'i Agricultural Diagnostic Service Center for $\mathrm{pH}$, extractable phosphorus $(\mathrm{P})$, potassium $(\mathrm{K})$, calcium $(\mathrm{Ca})$, and magnesium $(\mathrm{Mg})$. Each soil sample was composed of five subsamples taken from different locations within a field and composited. Soil $\mathrm{pH}$ was measured using the saturated paste method (Hue et al., 2000). The modified Truog method was used to analyze extractable $\mathrm{P}$ in soils with $\mathrm{pH}<7.0$. Ammonium acetate ( $1 \mathrm{M}$, $\mathrm{pH}$ 7.0) was used to extract soil cations, and $\mathrm{P}, \mathrm{K}, \mathrm{Ca}$, and $\mathrm{Mg}$ were analyzed using an inductively coupled plasma emission spectrophotometer [ICP (Optima 7000 DV; Perkin Elmer, Waltham, MA)] (Hue et al., 2000 ). Results of soil analyses were as follows: $\mathrm{pH}$ ranged from 5.8 to $6.1, \mathrm{P}$ ranged from 38 to $86 \mathrm{ppm}$, $\mathrm{K}$ ranged from 74 to $403 \mathrm{ppm}$, Ca ranged from 586 to $2356 \mathrm{ppm}$, and $\mathrm{Mg}$ ranged from 58 to $700 \mathrm{ppm}$.

Soil from Pepe'ekeo, HI, is a volcanic ash soil and considered a light soil. Soil $\mathrm{pH}$ was considered to be adequate, $\mathrm{P}$ ranged from low to adequate, $\mathrm{K}$ ranged from low to adequate, Ca was considered to be low, and $\mathrm{Mg}$ ranged from low to adequate (Yost and Uchida, 2000). Fertilizer rates were based on soil results and recommendations of Valenzuela et al. (1994). Phosphorus fertilizer $(0 \mathrm{~N}-$ $19.6 \mathrm{P}-0 \mathrm{~K})$ was banded before transplanting at $200 \mathrm{lb} /$ acre $\mathrm{P}$.

Sweetpotato trials were rain-fed. Rainfall during the time period of these field trials is shown in Fig. 1. Preemergent herbicide flumioxazin (Chateau $^{\circledR}$ Herbicide SW; Valent USA, Walnut Creek, CA) was sprayed at $1 \mathrm{oz} /$ acre a.i. $\approx 3 \mathrm{~d}$ before transplanting sweetpotato cuttings. Harvest dates were determined by observations of maturity of storage roots 
Table 1. Accession numbers/cultivar or landrace names (if available) of 12 sweetpotato entries, their U.S. state or country of origin, skin and flesh color, and frequency of inclusion in multiple field trials at Pepe'ekeo, HI.

\begin{tabular}{|c|c|c|c|c|c|}
\hline Accession no. & Cultivar/landrace & U.S. state or country & Skin color & Flesh color & Trials (no.) \\
\hline & Okinawan & Okinawa & White & Purple & 5 \\
\hline & Mokuau & Hawai'i & Red & Purple & 2 \\
\hline & Kona B & Hawai'i & Orange & Orange & 2 \\
\hline & Murasaki & Louisiana & Purple & White & 3 \\
\hline & LA $08-21 p$ & Louisiana & Red & Purple & 3 \\
\hline PI 531094 & 392 & Guatamala & Red & White & 5 \\
\hline PI 573330 & ACC 108 & Solomon Islands & Red & Light yellow & 5 \\
\hline PI 595199 & Darby & Louisiana & Pink & Orange & 5 \\
\hline PI 634398 & Pelican Processor & Louisiana & Tan & Light yellow & 5 \\
\hline PI 634399 & Picadito & Cuba & Red & White & 5 \\
\hline
\end{tabular}

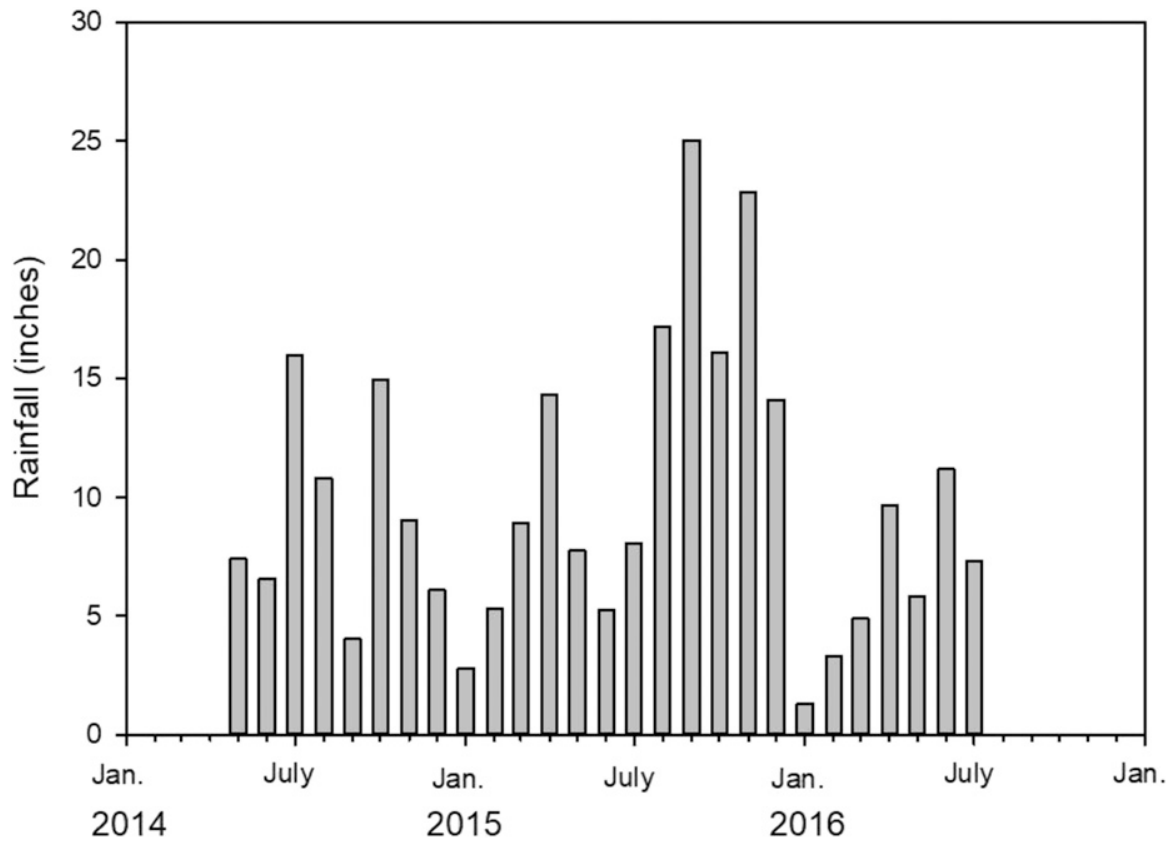

Fig. 1. Monthly rainfall at the Hilo International Airport located $\approx 10$ miles $(16.1 \mathrm{~km})$ from Pepe'ekeo, HI, field sites during May 2014 through July 2016 (National Weather Service, 2016); 1 inch $=2.54 \mathrm{~cm}$.

and could vary from 4.5 to 6 months. Typical cropping cycles of sweetpotato in Hawai' $i$ could range from 3 to 7 months, depending on rainfall, temperature, and other environmental conditions.

Field trial 1. Ten entries were planted on 8 May 2014 (Table 1). Fertilizer (23N-0P-29.9K) was broadcast on the surface of hills in equal amounts on 3 May, 23 June, and 23 July 2014, resulting in 300 $\mathrm{lb} /$ acre nitrogen $(\mathrm{N})$. Spinosad (Success Insecticide; Dow AgroSciences, Calgary, AB, Canada) was applied at $1.4 \mathrm{oz} /$ acre a.i. on 9 June, 23 July, and 20 Aug. 2014 to control planted on 1 Oct. 2014, and fertilizer $(23 \mathrm{~N}-0 \mathrm{P}-29.9 \mathrm{~K})$ was broadcast as described earlier on 15 Oct., 13 Nov., and 15 Dec. 2014, resulting in $300 \mathrm{lb} /$ acre N. Carbaryl (Sevin ${ }^{\circledR}$ XLR Plus; Bayer CropScience) was applied on 18 Nov. 2014 at 28 $\mathrm{oz} /$ acre a.i. to control rough sweetpotato weevil. Spinosad and imidacloprid were applied on 19 Dec. 2014 at rates described earlier. Storage roots were harvested after $\approx 4.5$ months on 18 Feb. 2015.

Field trial 3. In Trial 3, 'Mokuau' and 'Kona B', which had very low yields, were replaced with 'Murasaki-29' and 'LA 08-21p'. To help control rough sweetpotato weevil, we applied clothianidin (Belay ${ }^{\circledR} 16$ WSG; Valent USA) at $2.8 \mathrm{oz} /$ acre a.i. before planting. Cuttings were planted on 25 Feb. 2015, and fertilizer (23N$0 \mathrm{P}-29.9 \mathrm{~K})$ was broadcast on the surface of hills in equal amounts on 15 Mar., 8 Apr., and 6 May 2015, resulting in $100 \mathrm{lb} /$ acre N. Spinosad and imidacloprid were applied on $8 \mathrm{Apr}$. 2015, 6 May 2015, and 4 June 2015 at rates described earlier. In addition, carbaryl was applied twice on 22 Apr. 2015 and 20 May 2015 at the rate described earlier. Storage roots were harvested after nearly 5 months on 16 July 2015.

Field trial 4. The same 10 entries were planted as in trial 3 . Clothianidin was applied at the same rate as in trial 3 , immediately before planting, and then cuttings were planted on 15 July 2015. Fertilizer $(23 \mathrm{~N}-0 \mathrm{P}-29.9 \mathrm{~K})$ was broadcast as described earlier on 28 July, 26 Aug., and 23 Sept. 2015, resulting in $100 \mathrm{lb} /$ acre N. Spinosad and imidacloprid were applied at rates 
described earlier on 12 Aug., 8 Sept., and 8 Oct. 2015. Carbaryl was applied five times at the rate described earlier on 26 Aug., 23 Sept., 20 Oct., 4 Nov., and 22 Dec. 2015. Storage roots were harvested after nearly 6 months on 12 Jan. 2016.

Field tRIAL 5. In trial 5, we evaluated the same 10 entries as in trials 3 and 4. Clothianidin was applied before planting as described earlier, and cuttings were planted on 12 Jan. 2016. Fertilizer (23N-0P$29.9 \mathrm{~K})$ was applied as described earlier on 27 Jan., 23 Feb., and 23 Mar. 2016 , at the same rate as in trials 3 and 4. Spinosad and imidacloprid were applied on 9 Feb., 8 Mar., and 5 Apr. 2016, at the same rates as in Trials 3 and 4 . In addition, carbaryl was applied four times on $23 \mathrm{Feb}$., 24 Mar., 19 Apr., and 18 May 2016, at the same rate as in Trials 3 and 4 . Storage roots were harvested after 6 months on 19 July 2016.

Harvest. Sweetpotato vines were cut by hand sickles and removed from the field. Sweetpotato storage roots were dug using a sweetpotato harvester (BL-1050; Niplo, Ichinomiya-shi, Japan). This harvester is a chain digger that lifts storage roots from the soil, dropping them onto the surface.

Storage roots were washed and then graded first according to HDOA standards $[\mathrm{AA}, \mathrm{A}, \mathrm{B}$, and offgrades (HDOA, 1986)]. Grade AA storage roots had diameters between 1.75 and 3.25 inches, lengths between 3 and 9 inches, and fresh weights not more than $16 \mathrm{oz}$. Grade A storage roots had diameters between 1.75 and 3.75 inches, lengths between 3 and 10 inches, and fresh weights not more than $24 \mathrm{oz}$. Grade B storage roots had diameters not less than 1.75 inches and fresh weights not more than $32 \mathrm{oz}$. Offgrade storage roots had diameters less than 1.75 inches or fresh weights not more than $32 \mathrm{oz}$. The marketable category combined $\mathrm{AA}, \mathrm{A}$, and $\mathrm{B}$ grades.

Following this grading, storage roots were placed into subcategories: a) no injury, b) injury due to sweetpotato weevil, c) injury due to rough sweetpotato weevil, d) injury due to reniform nematodes (Rotylenchulus reniformis), and e) other surface defects (e.g., mechanical damage or rat damage). Sweetpotato weevil larvae bore into storage roots and produce characteristic black holes that if cut open reveal their presence (Clark et al., 2013). By contrast, larvae of rough sweetpotato weevil feed on the surface of storage roots, producing sunken trails (Pulakkatu-thodi et al., 2018). Damage due to reniform nematodes was characterized by sunken deformations or smooth cavities in storage roots (Clark et al., 2013). The number of storage roots in each subcategory was counted, and fresh weights were determined. Dry matter content was determined for each entry. Two representative storage roots without injury from each grade were cut into slices; fresh weights were measured, dried to constant weight at $60{ }^{\circ} \mathrm{C}$, and reweighed.

Sweetpotatoes were graded first, ignoring injury due to pests, and then the incidence of pests was recorded within each grade. Storage root yields and dimensions were considered to be due to cultivar and/or interactions with the environment; injury due to pests could be controlled by improved management practices.

Quality analysis. Compositional analyses were conducted for marketable storage roots harvested from trials 3, 4, and 5. Roots were cured in an incubator at $29.4{ }^{\circ} \mathrm{C}$ and $85 \%$ relative humidity for $5-7 \mathrm{~d}$ before being stored at $10{ }^{\circ} \mathrm{C}$ until analyzed. In each trial, 10 roots were assayed from each entry for internal color, moisture content, dry matter content, and starch and sugar concentrations. The purple-fleshed cultivars Okinawan and LA 08-2lp were assayed for anthocyanins. The yellow- or orange-fleshed entries 'Beauregard', PI 573330, 'Darby', and 'Pelican Processor' were assayed for carotenoids.

For internal flesh color, each storage root was peeled and sliced in half longitudinally, and internal flesh color was immediately measured at three locations lengthwise using a colorimeter (CR-400/410 with data processer DP-400; Konica Minolta, Ramsey, NJ). Ten storage roots for each cultivar per trial were cut into five slices that were frozen at $-80{ }^{\circ} \mathrm{C}$ for later carotenoid and anthocyanin assays. One slice from each of two storage roots of each entry was diced, combined, and weighed into tared metal weigh pans. Samples were dried to constant weight at $60{ }^{\circ} \mathrm{C}$ and weighed. Percent moisture and dry matter content were determined.
For carbohydrate analyses, one slice from each of two cured storage roots per entry was quickly diced and combined. A 10-g sample of tissue was immediately placed in $15 \mathrm{~mL}$ of $80 \%$ ethanol for sugar and starch assays. Sugar analysis was performed according to Wall (2004) using highperformance liquid chromatography [HPLC (1200 series; Agilent Technologies, Santa Clara, CA)]. A 20- $\mu$ L aliquot of sample was injected onto a $4.6 \times 150-\mathrm{mm}$ column [ 5 microns (Zorbax; Agilent Technologies)]. The mobile phase consisted of acetonitrile: water, $3: 1 \mathrm{v} / \mathrm{v}$, at a flow rate of $1.4 \mathrm{~mL} \cdot \mathrm{min}^{-1}$. A refractive index detector was used to detect sucrose, glucose, fructose, and maltose. Standards for each sugar were prepared at five concentrations for quantification.

Alcohol-insoluble solids (AISs) remaining from the sugar extractions were dried at $70{ }^{\circ} \mathrm{C}$ for $48 \mathrm{~h}$ and weighed. Starch content was determined by adding $30 \mathrm{mg}$ of AISs to 10 $\mathrm{mL}$ of deionized water and boiling for $90 \mathrm{~min}$ at $100{ }^{\circ} \mathrm{C}$. Samples were removed from the bath, capped, and cooled at room temperature overnight. Starch was assayed using enzymatic hydrolysis with amyloglucosidase, as described by Wall (2004).

Four sweetpotato entries with orange, salmon, or light-yellow flesh color were evaluated for their carotenoid content using a modified method of Wall et al. (2010). Sample slices that had been stored at $-80^{\circ} \mathrm{C}$ were used to prepare composite $20 \mathrm{~g}$ samples, containing a portion of each of three slices. Working under low light and cold temperatures, samples were placed into a $250-\mathrm{mL}$ beaker containing $2 \mathrm{~g}$ magnesium carbonate $\left(\mathrm{MgCO}_{3}\right), 40 \mathrm{~g}$ anhydrous sodium sulfate $\left(\mathrm{NaSO}_{4}\right)$, and $75 \mathrm{~mL}$ of cold tetrahydrofuran (THF). An outer beaker with ice water was used while homogenizing samples for $3 \mathrm{~min}$. The homogenate was filtered under vacuum, and the residue was rinsed with two volumes of THF. The filtrate was transferred to a $250-\mathrm{mL}$ volumetric flask and brought up to volume with THF. An aliquot (10 $\mathrm{mL}$ ) was placed into a glass vial and reduced to dryness under nitrogen gas $\left(\mathrm{N}_{2}\right)$. Dried samples were resuspended in $0.4 \mathrm{~mL}$ THF and vortexed. A $3.6-\mathrm{mL}$ mixture of acetonitrile: methanol, 1:1 (both HPLC grade), was then added and vortexed again. 
Samples were filtered through a 0.22$\mu \mathrm{m}$ nylon membrane syringe filter into 2-mL amber HPLC vials. An HPLC system (1200 series; Agilent Technologies) was used with a diode array detector, with maximum detection at $454 \mathrm{~nm}$. The mobile phase was acetonitrile: THF: water at a ratio of $85: 12.5: 2.5$, respectively, using all HPLC grade solvents. The flow rate was $0.3 \mathrm{~mL} \cdot \mathrm{min}^{-1}$. A $20-\mu \mathrm{L}$ aliquot of sample was injected onto a C-18 column [narrow bore, $100 \times 2.1 \mathrm{~mm}$, 5 microns (ODS Hypersil; Thermo Fisher Scientific, Waltham, MA)]. The column temperature was $40{ }^{\circ} \mathrm{C}$. Authentic standards of $\alpha$-carotene, $\beta$-carotene, $\beta$-cryptoxanthin, lutein, and lycopene were used for identification and quantification.

Anthocyanin content of two purple-fleshed cultivars was determined using the $\mathrm{pH}$ differential method of Giusti and Wrolstad (2001), as described by Oner and Wall (2012). Briefly, frozen sweetpotato samples were freeze-dried for $2 \mathrm{~d}$ at $-49^{\circ} \mathrm{C}$ (FreeZone 6; Labconco Corp., Kansas City, MO), ground into powder, extracted with $25 \mathrm{~mL}$ methanol/ water/hydrochloric acid $(\mathrm{HCl})$, filtered, and diluted 1:1 with the appropriate buffer [potassium chloride
$(0.025 \mathrm{M})$ at $\mathrm{pH} \mathrm{l}$ or sodium acetate $(0.4 \mathrm{M})$ at $\mathrm{pH} 4.5]$. Absorbance was measured at 530 and $700 \mathrm{~nm}$ using a spectrophotometer (SP-870; Barnstead International, Dubuque, IA) calibrated with distilled water as the blank. The absorbance difference between $\mathrm{pH} 1.0$ and $\mathrm{pH} 4.5$ samples was used to calculate total monomeric anthocyanins as milligrams anthocyanin per $100 \mathrm{~g}$ dry weight (milligrams cyanidin-3-glucoside per 100 g DW) (Oner and Wall, 2012). Percent polymeric color also was determined using the method described by Giusti and Wrolstad (2001).

STATISTICAL ANALYSIS OF YIELDS AND INSECT INJURY. "Multiple comparisons with the best" (MCB) was used to determine entries with the highest marketable fresh weight yields, total fresh weight yields, percent marketable yields relative to total yields, and incidence of sweetpotato weevil in marketable grades (in separate analyses). MCB was calculated using a macro in SAS software (version 9.2; SAS Institute, Cary, NC) (Westfall et al., 1999); it has the advantage of being an efficient multiple comparison that controls the experiment-wise error rate. It is similar to Duncan's multiple comparisons with a control in reducing the number of comparisons, without having to prespecify which cultivar is "best." After completion of a MCB procedure, cultivars can be categorized as being inferior to the best or among the best; in other words, there are only two groups.

The experimental design of the field trial consisted of a randomized complete block design with five blocks (i.e., trials replicated over time) and 12 entries evaluated at various frequencies (Table 1). When entries were absent at certain planting dates, they were treated as missing data. To determine whether there was a trend in marketable fresh weight yield over time, yield data of 'Okinawan' were regressed linearly over time using PROC GLM (SAS version 9.2). For compositional data, analysis of variance (ANOVA) was conducted for a randomized complete block design with three blocks (trials 3-5) and means were separated using the Waller-Duncan $k$-ratio test using SAS (version 9.4).

\section{Results}

YIELDS OF STORAGE ROOTS AND INJURY DUE TO INSECTS. Twelve sweetpotato entries differed significantly

Table 2. Twelve sweetpotato entries grown in five field trials at Pepe'ekeo, HI, that were replicated over time, and their marketable fresh weight yields, total fresh weight yields, marketable fresh weight yield relative to total yield, and incidence of sweetpotato weevil in marketable storage roots.

\begin{tabular}{|c|c|c|c|c|}
\hline \multirow[b]{2}{*}{ Entry } & $\begin{array}{l}\text { Marketable fresh wt yield } \\
\qquad\left(\mathrm{kg} \cdot \mathrm{ha}^{-1}\right)^{\mathrm{z}}\end{array}$ & $\begin{array}{l}\text { Total fresh wt yield } \\
\left(\mathrm{kg} \cdot \mathrm{ha} \mathrm{a}^{-1}\right)^{\mathrm{y}}\end{array}$ & $\begin{array}{c}\text { Marketable proportion } \\
(\% \text { of total) }\end{array}$ & $\begin{array}{l}\text { Weevils in marketable } \\
\text { storage roots }(\%)^{\mathrm{x}}\end{array}$ \\
\hline & \multicolumn{4}{|c|}{ Mean (SE) } \\
\hline Mokuau & $1,140(4,291) b$ & $2,828(7,123) b$ & $25.7(9.48) \mathrm{b}$ & $21.8(12.4) \mathrm{a}$ \\
\hline Kona B & $263(4,291) b$ & $2,199(7,123) b$ & $7.4(9.48) \mathrm{b}$ & $0.0(12.4) \mathrm{b}$ \\
\hline Murasaki & $11,575(3,504)$ a & $15,878(5,816)$ a & $70.2(7.74) \mathrm{a}$ & $6.5(10.1) b$ \\
\hline Beauregard & $17,149(2,714) a$ & $28,777(4,505)$ a & $57.2(5.99) \mathrm{a}$ & $36.9(7.8)$ a \\
\hline PI 573309 & $13,872(2,714) a$ & $25,626(4,505)$ a & $58.9(5.99)$ a & $12.1(7.8) b$ \\
\hline PI 573330 & $9,572(2,714) b$ & $30,490(4,505)$ a & $34.9(5.99) \mathrm{b}$ & $26.8(7.8) a$ \\
\hline Darby & $8,195(2,714) b$ & $15,379(4,505)$ a & $48.4(5.99) \mathrm{b}$ & $19.5(7.8) a$ \\
\hline Pelican Processor & $12,567(2,714) a$ & $19,866(4,505)$ a & $61.0(5.99) \mathrm{a}$ & $12.1(7.8) b$ \\
\hline
\end{tabular}

${ }^{\mathrm{z}}$ Marketable fresh weight yields are the sum of categories AA, A, and B (HDOA, 1986). Grade AA storage roots had diameters between 1.75 and 3.25 inches, lengths between 3 and 9 inches, and fresh weights not more than $16 \mathrm{oz}$. Grade A storage roots had diameters between 1.75 and 3.75 inches, lengths between 3 and 10 inches, and fresh weights not more than $24 \mathrm{oz}$. Grade B storage roots had diameters not less than 1.75 inches and fresh weights not more than $32 \mathrm{oz} ; 1 \mathrm{~kg} \cdot \mathrm{ha}=0.8922 \mathrm{lb} / \mathrm{acre} ; \mathrm{linch}=2.54 \mathrm{~cm} ; 1 \mathrm{oz}=$ $28.3495 \mathrm{~g}$.

${ }^{\mathrm{y}}$ Total yields are the sum of fresh weight yields of marketable and offgrade (HDOA, 1986) storage roots. Offgrade storage roots had diameters less than 1.75 inches or fresh weights more than $32 \mathrm{oz}$.

${ }^{x}$ Sweetpotatoes were graded first, ignoring injury due to pests, and then incidence of pests was recorded within each grade. Storage root yields and dimensions were considered to be due to cultivar and/or interactions with the environment; however, injury due to pests could be controlled by improved management practices.

${ }^{\mathrm{w}}$ Letters in a column that are the same indicate no significant difference $(P<0.05)$ of that mean from the greatest value using multiple comparisons with the best and are highlighted in bold text. 
in marketable fresh weight yield and total fresh weight yield (Table 2). 'LA 08-2lp' had the best marketable fresh weight yield of storage roots. Other entries that did not differ from the best with regard to marketable fresh weight yield were 'Murasaki-29', 'Beauregard', PI 573309, 'Pelican Processor', and 'Picadito'. 'LA 0821 ' also had the best total fresh weight yield of storage roots. With regard to total fresh weight yields, other entries that did not differ from the best were 'Murasaki-29', 'Beauregard', PI 573309, PI 573330, 'Darby', 'Pelican Processor', and 'Picadito'. Results for marketable dry weight yield and total dry weight yield were similar and are not shown here. No significant trend in marketable fresh weight yield of 'Okinawan' was found over time $[P=0.32$ (data not shown)].

Twelve sweetpotato entries differed significantly in proportion of marketable storage roots (percent total fresh weight) and incidence of sweetpotato weevil in marketable storage roots (Table 2). 'Picadito' had the greatest proportion of marketable storage roots relative to the total fresh weight yield. Other entries that did not differ from the best were 'Okinawan', 'Murasaki-29', 'LA 08$21 \mathrm{p}$ ', 'Beauregard', PI 573309, and 'Pelican Processor'. 'LA 08-21p' had the greatest incidence of sweetpotato weevils in marketable storage roots. Entries that differed significantly from the greatest damage (i.e., may have some resistance) were 'Okinawan', 'Kona B', 'Murasaki-29', PI 573309, 'Pelican Processor', and 'Picadito'.

There were no significant differences among entries in incidence of reniform nematodes or rough sweetpotato weevil $(P=0.41$ or $P=0.33$, respectively). The overall means of incidence of reniform nematodes and rough sweetpotato weevil damage within marketable storage roots (based on fresh weight) were $( \pm \mathrm{SE})$ $5.3 \% \pm 11.18 \%$ and $25.8 \% \pm 3.73 \%$, respectively. The overall mean of percent dry matter in marketable storage roots was $30.5 \% \pm 7.88 \%$.

QUALITY OF STORAge ROOTS. Sucrose was the predominant sugar in all raw sweetpotato roots analyzed (Table 3 ). Total sugars were highest for 'Beauregard', followed by 'Murasaki-29' and 'Darby'. Total sugars for all entries ranged from 45.18 to $76.88 \mathrm{mg} \cdot \mathrm{g}^{-1}$ fresh weight (FW) and were higher than those listed $\left(41.8 \mathrm{mg} \cdot \mathrm{g}^{-1} \mathrm{FW}\right)$ in the USDA Food Composition Database for raw, orange-fleshed roots (USDA, 2018). 'Beauregard', 'Murasaki', and 'Okinawan' had the three highest sucrose concentrations. Sweetness is related to soluble sugars, especially sucrose, and a sensory panel rated the cooked roots of these cultivars as medium sweet (data not shown). Sugar profiles for PI 573330, 'Darby', and PI 531094 showed greater amounts of glucose and fructose, relative to the other entries. These cultivars tended to have lower sucrose and total sugar contents. No cultivar contained high levels of sucrose and monosaccharides, similar to a report by LaBonte et al. (2000). The root dry matter content was highest for 'Picadito', 'Okinawan', and 'Murasaki-29'
(Table 4). Similarly, 'Okinawan', PI 531094, 'Murasaki-29', and 'Picadito' roots had the highest starch content. The range of values for soluble sugars and starch contents generally agrees with other reports for sweetpotato cultivars (LaBonte et al., 2000; Picha, 1985; Van Den et al., 1986; Wall, 2005). The dry matter content exceeded $30 \%$ for most of the white-fleshed cultivars and for 'Okinawan'.

Surface color measurements of sweetpotato roots revealed that 'Okinawan' had a deeper purple internal flesh than 'LA 08-21p'. 'Beauregard' had a brighter orange flesh than 'Darby' (Table 5). The white-fleshed entries were characterized by dull, light-grayish-yellow interior.

Sweetpotatoes with orange or light-yellow flesh were analyzed for $\beta$-carotene content; however, $\beta$-carotene was not detected in the

Table 3. Sugar (fructose, glucose, sucrose, maltose, and total) concentrations of 10 sweetpotato entries grown at Pepe'ekeo, HI.

\begin{tabular}{llcccc}
\hline & Fructose & Glucose & \multicolumn{1}{c}{ Sucrose } & Maltose & Total sugars \\
\cline { 2 - 6 } Entry & \multicolumn{4}{c}{$\left(\mathbf{m g} \cdot \mathbf{g}^{-\mathbf{1}} \text { fresh } \mathbf{~ w t}\right)^{\mathbf{z}}$} \\
\hline Okinawan & $0.77 \mathrm{fg}^{\mathrm{y}}$ & $2.50 \mathrm{f}$ & $50.03 \mathrm{c}$ & $0.44 \mathrm{~b}$ & $53.29 \mathrm{~cd}$ \\
Murasaki-29 & $0.51 \mathrm{~g}$ & $2.58 \mathrm{f}$ & $56.38 \mathrm{~b}$ & $0.77 \mathrm{ab}$ & $59.96 \mathrm{~b}$ \\
LA 08-21p & $4.70 \mathrm{c}$ & $11.78 \mathrm{c}$ & $38.59 \mathrm{fg}$ & $0.57 \mathrm{ab}$ & $52.40 \mathrm{cde}$ \\
PI 531094 & $6.81 \mathrm{~b}$ & $14.27 \mathrm{ab}$ & $36.25 \mathrm{~g}$ & $0.80 \mathrm{ab}$ & $52.18 \mathrm{cde}$ \\
Beauregard & $3.04 \mathrm{~d}$ & $7.19 \mathrm{~d}$ & $68.38 \mathrm{a}$ & $0.51 \mathrm{~b}$ & $76.88 \mathrm{a}$ \\
PI 573309 & $1.43 \mathrm{ef}$ & $4.00 \mathrm{ef}$ & $46.84 \mathrm{~cd}$ & $1.07 \mathrm{a}$ & $52.41 \mathrm{cde}$ \\
PI 573330 & $8.47 \mathrm{a}$ & $16.23 \mathrm{a}$ & $25.29 \mathrm{~h}$ & $0.49 \mathrm{~b}$ & $45.18 \mathrm{f}$ \\
Darby & $7.49 \mathrm{~b}$ & $13.89 \mathrm{~b}$ & $38.78 \mathrm{efg}$ & $0.70 \mathrm{ab}$ & $55.74 \mathrm{bc}$ \\
Pelican processor & $2.07 \mathrm{e}$ & $5.24 \mathrm{de}$ & $43.78 \mathrm{ed}$ & $0.58 \mathrm{ab}$ & $50.28 \mathrm{def}$ \\
Picadito & $1.75 \mathrm{e}$ & $4.02 \mathrm{ef}$ & $42.48 \mathrm{def}$ & $0.53 \mathrm{~b}$ & $47.79 \mathrm{ef}$ \\
\hline
\end{tabular}

${ }^{\mathrm{z}}$ Values are means of three replications, with 10 roots per replication; $1 \mathrm{mg} \cdot \mathrm{g}^{-1}=1,000 \mathrm{ppm}$.

${ }^{y}$ Means within columns followed by the letter are not significantly different according to the Waller-Duncan $k$-ratio test $(P \leq 0.05)$.

Table 4. Dry matter and starch content of 10 sweetpotato entries grown at Pepe'ekeo, HI. $^{\text {z }}$

\begin{tabular}{lcc}
\hline Entry & Dry matter (\%) & Starch (\%) \\
\hline Okinawan & $31.91 \mathrm{ab}^{\mathbf{x}}$ & $63.92 \mathrm{a}$ \\
Murasaki-29 & $31.28 \mathrm{ab}^{\mathrm{b}}$ & $60.82 \mathrm{ab}$ \\
LA 08-2lp & $27.22 \mathrm{c}$ & $52.99 \mathrm{c}$ \\
PI 531094 & $25.86 \mathrm{~cd}$ & $57.03 \mathrm{bc}$ \\
Beauregard & $21.85 \mathrm{f}$ & $38.80 \mathrm{e}$ \\
PI 573309 & $30.64 \mathrm{~b}$ & $61.53 \mathrm{ab}$ \\
PI 573330 & $24.47 \mathrm{de}$ & $57.93 \mathrm{~b}$ \\
Darby & $23.78 \mathrm{ef}$ & $47.63 \mathrm{~d}$ \\
Pelican processor & $30.56 \mathrm{~b}$ & $58.52 \mathrm{~b}$ \\
Picadito & $32.58 \mathrm{a}$ & $60.66 \mathrm{ab}$ \\
\hline
\end{tabular}

${ }^{\mathrm{z}}$ Values are means of three replications, with 10 storage roots per replication.

${ }^{y}$ Percent starch is expressed on a dry weight basis.

${ }^{\mathrm{x}}$ Means within columns followed by the same letter are not significantly different according to the Waller-Duncan $k$-ratio test $(P \leq 0.05)$. 
light-yellow roots of PI 573330 and 'Pelican Processor' (Table 6). $\beta$-carotene concentrations were high in 'Beauregard' and 'Darby'. The vitamin A content from $\beta$-carotene alone was 692 and $457 \mu \mathrm{g} / 100 \mathrm{~g}$ FW retinol activity equivalents (RAE) for 'Beauregard' and 'Darby', respectively. The vitamin A content of 'Beauregard' is similar to that reported in the USDA database $[709 \mu \mathrm{g} / 100 \mathrm{~g}$ FW (raw root) RAE]) (USDA, 2018). Consumption of these sweetpotatoes $(100 \mathrm{~g})$ nearly meets the recommended dietary allowance (RDA) per day for vitamin A for men (900 $\mu \mathrm{g}$ RAE) and women $(700 \mu \mathrm{g}$ RAE) (Institute of Medicine, 2001).

Purple-fleshed storage roots of 'Okinawan' and 'LA 08-2lp' were analyzed for anthocyanin contents. The total monomeric anthocyanin content was similar for both the cultivars $(37.3$ and $33.5 \mathrm{mg} / 100 \mathrm{~g}$ FW for 'Okinawan' and 'LA 08$21 p$ ', respectively) but less than that of previous reports for uncooked 'Okinawan' roots $(57.4 \mathrm{mg} / 100 \mathrm{~g}$ FW) (Oner and Wall, 2013). Polyphenol oxidase activity may have catalyzed the conversion of monomeric to polymeric anthocyanins during postharvest handling, as indicated by $29 \%$ to $32 \%$ polymeric forms. Although the antioxidant activity was not measured in this study, Hager et al. (2008) suggested that both monomeric and polymeric forms of anthocyanins contribute to the antioxidant activity. Anthocyanin concentration and antioxidant activity are strongly correlated in purplefleshed sweetpotato roots (Philpott et al., 2004). Previously, purplefleshed cultivars with anthocyanins ranging from 5.3 to $53.6 \mathrm{mg} / 100 \mathrm{~g}$ FW showed higher free radical scavenging activity and antioxidant activity when compared with white-, yellow-, or orange-fleshed cultivars (Furuta et al., 1998).

\section{Discussion}

'LA 08-2lp' is a promising purple-fleshed cultivar for growth along the east coast of Hawai ${ }^{i} i$ Island, with the best fresh or dry weight marketable yield of storage roots, and the best total fresh or dry weight yield of the entries that we evaluated. Its marketable yield was almost six times greater than that of the commercial landrace 'Okinawan', another purplefleshed sweetpotato. This cultivar and 'Murasaki-29' were grown only in the latter three field trials, and a question was raised whether significant differences in yield occurred over time, possibly resulting in artificially higher yields of these two cultivars. Linear regression analysis was conducted with marketable yields of 'Okinawan' over five cropping cycles, and no significant effect due to time was found.

A major problem, however, with 'LA 08-2lp' is that it also had the greatest incidence of sweetpotato weevil damage in this study on Hawai' $i$ Island and in field trials on Maui Island (Miyasaka et al., 2018). Its growth habit produced storage roots in a tight cluster near the soil surface, making it easy to harvest. Such morphology could make it easier for sweetpotato weevils to locate and injure storage roots. Hahn and Leuschner (1982) found that sweetpotato weevils cannot mine easily through soil and normally attack only the exposed upper parts of storage roots. A negative correlation was found between resistance of cultivars

Table 5. Internal flesh color [lightness $\left(\mathrm{L}^{*}\right)$, chroma $\left(\mathrm{C}^{*}\right)$, hue angle $(\mathrm{h})^{\circ}$, and internal description] of 10 sweetpotato entries grown at Pepe'ekeo, HI. ${ }^{\mathrm{z}}$

\begin{tabular}{lcccc}
\hline Entry & Lightness $\left(\mathbf{L}^{*}\right)$ & Chroma $\left(\mathbf{C}^{*}\right)$ & Hue angle $(\mathbf{h})^{\circ}$ & Internal description \\
\hline LA 08-2lp & $57.62 \mathrm{a}^{\mathrm{y}}$ & $25.90 \mathrm{~b}$ & $358.08 \mathrm{a}$ & Purple \\
Mokuau & $50.36 \mathrm{~b}$ & $27.51 \mathrm{a}$ & $340.02 \mathrm{~b}$ & Purple \\
Murasaki-029 & $86.99 \mathrm{ab}$ & $29.69 \mathrm{a}$ & $97.15 \mathrm{a}$ & White \\
PI 531094 & $86.89 \mathrm{ab}$ & $28.57 \mathrm{a}$ & $98.06 \mathrm{a}$ & White \\
PI 573309 & $87.44 \mathrm{ab}$ & $12.42 \mathrm{~d}$ & $96.45 \mathrm{a}$ & White \\
Picadito & $87.81 \mathrm{a}$ & $11.50 \mathrm{~d}$ & $94.23 \mathrm{a}$ & White \\
Pelican processor & $85.20 \mathrm{c}$ & $26.72 \mathrm{~b}$ & $95.50 \mathrm{a}$ & Light yellow \\
PI 573330 & $86.06 \mathrm{bc}$ & $20.86 \mathrm{c}$ & $98.41 \mathrm{a}$ & Light yellow \\
Darby & $75.22 \mathrm{a}$ & $45.65 \mathrm{~b}$ & $64.60 \mathrm{a}$ & Orange \\
Beauregard & $71.99 \mathrm{~b}$ & $54.06 \mathrm{a}$ & $60.77 \mathrm{a}$ & Orange/salmon
\end{tabular}

${ }^{\mathrm{z}}$ Values are means of three replications, with 10 storage roots per replication.

${ }^{\mathrm{y}}$ Means within columns (by color grouping) followed by the letter are not significantly different according to the Waller-Duncan $k$-ratio test $(P \leq 0.05)$.

Table 6. $\beta$-carotene content, vitamin A content, and flesh color of four orange- or yellow-fleshed sweetpotato entries grown at Pepe'ekeo, HI.

\begin{tabular}{|c|c|c|c|}
\hline \multirow[b]{2}{*}{ Entry } & $\beta$-carotene $(\mu \mathrm{g} / 100 \mathrm{~g} \mathrm{FW})^{\mathrm{z}}$ & Vitamin A $[\operatorname{RAE}(\mu \mathrm{g} / 100 \mathrm{~g} \mathrm{FW})]^{\mathrm{z}}$ & Flesh color \\
\hline & \multicolumn{3}{|c|}{ Mean \pm SE $^{y}$} \\
\hline Beauregard & $8,301.7 \pm 733.6$ & $691.8 \pm 61.1$ & Orange/salmon \\
\hline Darby & $5,485.2 \pm 343.5$ & $457.1 \pm 28.6$ & Orange \\
\hline Pelican processor & nd & nd & Light yellow \\
\hline
\end{tabular}

${ }^{\mathrm{z}} \mathrm{FW}=$ fresh weight; RAE $=$ retinol activity equivalents; $1 \mu \mathrm{g} / 100 \mathrm{~g}=10 \mathrm{ppb}$.

${ }^{\mathrm{y}}$ Means of three replications, with 10 roots per replication.

${ }^{\mathrm{x}}$ Not detectable. 
to African sweetpotato weevil (Cylas puncticollis) and the distance from the soil surface to the top of the storage root (Stathers et al., 2003b).

'Beauregard' is another promising orange-fleshed cultivar with a marketable fresh weight yield that did not differ from the best; however, its damage due to sweetpotato weevil was high at $36.9 \%$ (second highest damage). 'Beauregard' is one of the leading commercial orange-fleshed cultivars in Louisiana; however, it is considered to be insect susceptible with high damage to storage roots by several insects, including sweetpotato weevil (Jackson and Harrison, 2013; Jackson et al., 2012; Thompson et al., 1999). Interestingly, Jackson et al. (2012) reported that 'Beauregard' did not perform well under tropical conditions in the Caribbean; however, this conclusion was not true for its growth under tropical conditions of Hawai'i Island.

'Murasaki-29' is a promising white-fleshed cultivar that did not differ from the best in marketable fresh or dry weight yields and showed some indication of resistance to sweetpotato weevil. Jackson and Harrison (2013) reported that 'Murasaki-29' was especially resistant to sweetpotato weevil attack under relatively low population levels at Charleston, SC. Apparently, under high population levels of sweetpotato weevil on Hawai' $i$ Island, 'Murasaki-29' still demonstrated weevil resistance.

'Picadito' (PI 634399) is a promising white-fleshed cultivar that did not differ from the best in marketable fresh or dry weight yields and showed some indication of resistance to sweetpotato weevil. It also had the highest proportion of the marketable fresh weight yield of all entries than the total root yield at $73.9 \%$. 'Picadito' is a commercial boniato-type (i.e., white and dry-fleshed) sweetpotato grown widely in southern Florida (Jackson and Bohac, 2006) for the ethnic Caribbean, Latin American, and African markets. It has been reported to be more resistant to sweetpotato weevil than susceptible control cultivars (Jackson and Bohac, 2006). Total sugars for 'Picadito' were the second lowest.

Jackson and Bohac (2006) reported that it was difficult to develop an intensive recurrent breeding program that targets sweetpotato weevil resistance because there was a lack of consistent high weevil pressure for selection in Charleston, SC. By contrast, Hawai'i Island has a very high consistent population of sweetpotato weevils and would be an ideal location for a breeding program that targets sweetpotato weevil resistance.

\section{Conclusion}

Both 'Okinawan' and 'LA 082lp' are purple-fleshed cultivars that contain healthful anthocyanins. 'LA 08-2lp' had the greatest marketable yields; however, it also had the greatest incidence of damage due to sweetpotato weevil, perhaps because of its growth habit of a tight cluster of storage roots located close to the soil surface. Both 'Beauregard' and 'Darby' are orange-fleshed cultivars that contain the healthful antioxidant $\beta$-carotene. 'Beauregard' also had the highest sucrose concentration; however, it was susceptible to sweetpotato weevil, exhibiting the second worst incidence of injury to this pest. Information in this article could assist growers in selection of appropriate sweetpotato cultivars to plant. Also, these data could help plant breeders improve the germplasm for both quality and resistance to pests, such as sweetpotato weevil.

\section{Literature cited}

Clark, C.A., D.M. Ferrin, T.P. Smith, and G.J. Holmes. 2013. Compendium of sweetpotato diseases, pests, and disorders. 2nd ed. APS Press, St. Paul, MN.

Follett, P.A. 2006. Irradiation as a methyl bromide alternative for postharvest control of Omphisa anastomosalis (Lepidoptera: Pyralidae) and Euscepes postfasciatus and Cylas formicarius elegantulus (Coleoptera: Curculionidae) in sweetpotatoes. J. Econ. Entomol. 99:32-37.

Furuta, S., I. Suda, Y. Nishiba, and O. Yamakawa. 1998. High tert-butylperoxyl radical scavenging activities of sweet potato cultivars with purple flesh. Food Sci. Technol. Intl. Tokyo 4:33-35.

Giusti, M.M. and R.E. Wrolstad. 2001. Characterization and measurement of anthocyanins by UV-visible spectroscopy. Current protocols in food analytical chemistry. F1.2.1-F1.2.13.

Hager, A., L.R. Howard, R.L. Prior, and C. Brownmiller. 2008. Processing and storage effects on monomeric anthocyanins, percent polymeric color, and antioxidant capacity of processed black raspberry products. J. Food Sci. 73: H134-H140.

Hahn, S.K. and K. Leuschner. 1982. Breeding sweet potato for weevil resistance, p. 331-336. In: R.L. Villareal and T.D. Griggs (eds.). Sweet potato: Proceedings of the First International Symposium, AVRDC Publication No. 82-172.

Hawaici Department of Agriculture. 1986. Standards for Hawaii-grown sweet potatoes. Hawai'i Dept. Agr., Honolulu, HI. 27 Sept. 2019. <https://hdoa. hawaii.gov/qad/files/2012/12/AR-4157.pdf>.

Hawai'i Department of Agriculture. 2004. Statistics of Hawai'i agriculture 2002. Hawai'i Dept. Agr./U.S. Dept. Agr., Agr. Stat. Serv., Honolulu, HI.

Hawai'i Department of Agriculture. 2013. Statistics of Hawai'i agriculture 2011. Hawai'i Dept. Agr./U.S. Dept. Agr., Agr. Stat. Serv., Honolulu, HI.

Hawai'i Department of Agriculture. 2018. Hawaii vegetable and melon crops report. 13 June 2018. <https:// www.nass.usda.gov/Statistics_by_State/ Hawaii/Publications/Vegetables/2017/ 20170 lvegrv.pdf>.

Hue, N.V., R. Uchida, and M.C. Ho. 2000. Sampling and analysis of soils and plant tissues: How to take representative samples, how the samples are tested, p. 23-30. In: J.A. Silva and R. Uchida (eds.). Plant nutrient management in Hawaii's soils, approaches for tropical and subtropical agriculture. 2 Aug. 2016. <http:// www.ctahr.hawaii.edu/oc/freepubs/pdf/ pnm2.pdf>.

Institute of Medicine. 2001. Dietary reference intakes for vitamin $\mathrm{A}$, vitamin $\mathrm{K}$, arsenic, boron, chromium, copper, iodine, iron, manganese, molybdenum, nickel, silicon, vanadium, and zinc. Natl. Acad. Press, Washington, DC.

Jackson, D.M. and J.R. Bohac. 2006. Improved dry-fleshed sweetpotato genotypes resistant to insect pests. J. Econ. Entomol. 99:1877-1883.

Jackson, D.M. and H.F. Harrison, Jr. 2013. Insect resistance in traditional and heirloom sweetpotato varieties. J. Econ. Entomol. 106:1456-1462.

Jackson, D.M., H.F. Harrison, Jr., and J.R. Ryan-Bohac. 2012. Insect resistance in sweetpotato plant introduction accessions. J. Econ. Entomol. 105:651-658.

LaBonte, D.R., D.H. Picha, and H.A. Johnson. 2000. Carbohydrate-related changes in sweetpotato storage roots during development. J. Amer. Soc. Hort. Sci. 125:200-204. 
LaBonte, D.R., A.Q. Villordon, C.A. Clark, P.W. Wilson, and C.S. Stoddard. 2008. 'Murasaki-29' sweetpotato. HortScience 43:1895-1896.

Miyasaka, S.C., S. Motomura-Wages, C.A. Clark, D.R. LaBonte, and A.Q. Villordon. 2018. Field Performance of tissue-cultured, virus-tested 'Okinawan' sweetpotato and comparison with some promising cultivars in Hawai'i. HortTechnology 28: 676-683.

National Weather Service. 2016. NOWData-NOAA online weather data, Climatological data for Hilo Area, HI. 22 June 2019. <https://w2.weather.gov/ climate $/$ xmacis.php?wfo $=\mathrm{hnl}>$.

Nottingham, S.F. and S.J. Kays. 2002. Sweetpotato weevil control. Acta Hort. 583:155-161.

Oner, M.E. and M.M. Wall. 2012. Processing conditions for producing French fries from purple-fleshed sweetpotatoes. Trans. Amer. Soc. Agr. Biol. Eng. 55: 2285-2291.

Oner, M.E. and M.W. Wall. 2013. Quality of fresh-cut purple sweet potatoes after x-ray irradiation treatment and refrigerated storage. Intl. J. Food Sci. Technol. 48:2064-2070.

Philpott, M., K.S. Gould, C. Lim, and L.R. Ferguson. 2004. In situ and in vitro antioxidant activity of sweetpotato anthocyanins. J. Agr. Food Chem. 52: 1511-1513.

Picha, D.H. 1985. HPLC determination of sugars in raw and baked sweet potatoes. J. Food Sci. 50:1189-1190.
Pulakkatu-thodi, I., S. Motomura, and S. Miyasaka. 2018. Evaluation of insecticides for the management of rough sweetpotato weevil, Blosyrus asellus (Coleoptera: Curculionidae) in Hawai' $i$ Island. Crop Prot. 114:223-227.

Stathers, T.E., D. Rees, S. Kabi, L. Mbilinyi, N. Smit, H. Kiozya, S. Jeremiah, A. Nyango, and D. Jeffries. 2003a. Sweetpotato infestation by Clyas spp. in east Africa: I. Cultivar differences in field infestation and the role of plant factors. Intl. J. Pest Mgt. 49:131-140.

Stathers, T.E., D. Rees, A. Nyango, H. Kiozyas, L. Mbilinyi, S. Jeremiah, S. Kabi, and N. Smit. 2003b. Sweetpotato infestation by Cylas spp. in east Africa: II. Investigating the role of root characteristics. Intl. J. Pest Mgt. 49:141-146.

Teow, C.C., V-D. Truon, R.F. McFeeters, R.L. Thompson, K.V. Pecota, and G.C. Yencho. 2007. Antioxidant activities, phenolic and beta-carotene contents of sweet potato genotypes with varying flesh colours. Food Chem. 103:829-838.

Thompson, P.G., J.C. Schneider, B. Graves, and R.C. Sloan, Jr. 1999. Insect resistance in sweetpotato plant introductions. HortScience 34:711-714.

U.S. Department of Agriculture. 2018. National nutrient database for standard reference 1 release Apr. 2018. 6 June 2019. $<$ https://ndb.nal.usda.gov/ndb/>.

Van Den, T.C., C.J. Biermann, and J.A. Marlett. 1986. Simple sugars, oligosaccharides, and starch concentrations in raw and cooked sweet potato. J. Agr. Food Chem. 34:421-425.
Valenzuela, H., S. Fukuda, and A. Araki. 1994. Sweetpotato production guides for Hawai'i. 22 June 2019. <https://www. ctahr.hawaii.edu/oc/freepubs/pdf/ RES-146.pdf>.

Wall, M.M. 2004. Compositional and sensory analyses of sweetpotatoes after $\mathrm{x}$ ray irradiation quarantine treatment. HortScience 39:574-577.

Wall, M.M. 2005. Storage quality and composition of sweetpotato roots after quarantine treatment using low doses of $\mathrm{x}$-ray irradiation. HortScience 40:424427.

Wall, M.M., K.A. Nishijima, M.M. Fitch, and W.T. Nishijima. 2010. Physicochemical, nutritional, and microbial quality of fresh-cut and frozen papaya from cultivars with varying resistance to internal yellowing disease (Enterobacter cloacae). J. Food Qual. 33:131-149.

Wang, S., S. Nie, and F. Zhu. 2016. Chemical constituents and health effects of sweet potato. Food Res. Intl. 89:90116.

Westfall, P.H., R.D. Tobias, D. Rom, R.D. Wolfinger, and Y. Hochberg. 1999. Multiple comparisons and multiple tests: Using SAS. SAS Institute, Cary, NC.

Yost, R.S. and R. Uchida. 2000. Interpreting soil nutrient analysis data: Definition of "low," "sufficient," and "high" nutrient levels, p. 87-89. In: J.A. Silva and R. Uchida (eds.). Plant nutrient management in Hawaii's soils, approaches for tropical and subtropical agriculture. 25 May 2017. <https://www.ctahr.hawaii. edu/oc/freepubs/pdf/pnm7.pdf>. 